\title{
KAJIAN YURIDIS FUNGSI PENCEGAHAN KOMISI PEMBERANTASAN \\ KORUPSI DALAM PEMBERANTASAN TINDAK PIDANA KORUPSI \\ PENGADAAN BARANG DAN JASA SECARA ELEKTRONIK DI PROVINSI \\ DKI JAKARTA
}

\author{
Oleh: \\ Mahardika \\ (Mahasiswa Program S1 Fakultas Hukum Universitas Tarumanagara) \\ (Email: maharr_dika@yahoo.com)
}

\section{Firman Wijaya}

(Corresponding Author)

Dosen Tidak Tetap Hukum Pidana di Fakultas Hukum Universitas Tarumanagara, Meraih Sarjana

Hukum dari Fakultas Hukum Universitas Tarumanagara, Magister Hukum dari Fakultas Hukum

Universitas Tujuh Belas Agustus 1945, Doktor Ilmu Hukum dari Fakultas Hukum Universitas

Krisnadwipayana

(Email: mhunkris@yahoo.com)

\begin{abstract}
In Indonesia, corruption is rampant in the procurement of goods and services. The institution authorized to deal with corruption is the Corruption Eradication Commission (KPK). One of the tasks of the Corruption Eradication Commission is to carry out surveillance and preventive actions so that there are not many corruption cases that can harm the country but the prevention function has not been maximally implemented. Therefore, the author proposes the issue of how is the juridical study of Corruption Eradication Commission's preventive function in eradicating corruption of the electronic procurement of goods and services in DKI Jakarta province? The author analizes the problem using normative research methods, with the technique of research legislation approaches. Corruption in the procurement of goods and services is very widespread because there are still gaps or weaknesses used to commit corruption. Existing weaknesses include regulation, principles in procurement of goods and services, supervision, and implementation of procurement of goods and services. Likewise, the implementation of KPK in terms of prevention is still lacking. The KPK should be an institution tasked with eradicating corruption. In addition to supervision, the KPK should prioritize implementing prevention so that corruption does not occur. The thing that can be done by KPK includes tightening supervision in the procurement of goods and services.

Keywords: Prevention, Corruption Eradication Commission, Corruption, Procurement of Goods and Services, Electronic.
\end{abstract}




\section{Pendahuluan}

\section{A. Latar Belakang}

Hukum merupakan suatu aturan yang berlaku di setiap negara yang sudah secara tegas dan diberlakukan untuk masyarakat dan pada hakikatnya hukum tidak lain adalah perlindungan kepentingan manusia, yang berbentuk kaidah atau norma. ${ }^{1)}$ Fungsi hukum adalah untuk menjamin keteraturan dan ketertiban masyarakat. ${ }^{2)}$ Negara Indonesia adalah negara hukum mempunyai arti bahwa Indonesia merupakan negara yang memegang teguh dan menjunjung tinggi hukum dengan berlandaskan hukum yang ada (rechtstaat) dalam melaksanakan pemerintahannya, tanpa melihat kekuasaan semata (machstaat). ${ }^{3)}$ Konsep hukum yang berlaku di Indonesia diatur dalam UndangUndang Dasar Negara Republik Indonesia Tahun 1945.

Indonesia pada saat ini belum bisa dikatakan sebagai negara maju dimana masih membutuhkan waktu untuk berkembang, maka Indonesia terus berusaha mewujudkan masyarakat adil dan makmur. Cara untuk mencapai hal tersebut, maka harus meningkatkan kualitas di bidang hukum demi tercapainya pembangunan diseluruh bidang. Dan juga meningkatkan kualitas dari penegak hukum untuk mencapai kepastian dan ketertiban hukum yang menimbulkan kewibawaan para penegak hukum agar sesuai dengan fungsi dan wewenangnya.

Manusia merupakan makhluk sosial yang berarti manusia tidak dapat hidup sendiri, tetapi membutuhkan bantuan manusia lain untuk hidup. Dalam membutuhkan bantuan dari manusia lain, maka timbulah interaksi atau hubungan antara manusia yang satu dengan manusia lainnya. Pemenuhan kebutuhan hidup tergantung dari hasil yang diperoleh melalui daya upaya yang dilakukan untuk memperoleh kemakmuran dan kesejahteraan lahir dan

1) Sudikno Mertokusumo, Bunga Rampai Ilmu Hukum, Cetakan ke-1, (Yogyakarta: Liberty, 1984), hal.1.

${ }^{2)}$ Mochtar Kusumaatmadja dan Arief Sidharta, Pengantar Ilmu Hukum Suatu Pengenalan Pertama Ruang Lingkup Berlakuknya Ilmu Hukum, Buku I, (Bandung: Penerbit Alumni, 2000), hal.50.

${ }^{3)}$ Indonesia, Undang Undang Dasar Negara Republik Indonesia 1945 Pasal 1 Ayat (3). 
batin. ${ }^{4)}$ Tentunya dalam interaksinya manusia memerlukan peraturan-peraturan untuk memberikan batasan dalam mereka bertindak.

Hal ini dapat diwujudkan yang mana bergantung kepada tingkah laku dan hidup sesuai dengan norma yang berlaku di masyarakat. Perbuatan manusia yang tidak sesuai dengan norma dan peraturan yang ada, menimbulkan ketidak seimbangannya tata tertib yang ada dimasyarakat. Perbuatan yang tidak sesuai dengan norma teresbut, sering diibaratkan sebagai pelanggaran bahkan kejahatan. Perbuatan pelanggaran tersebut merupakan hal yang menimbulkan keresahan bagi setiap masyarakat, bahkan negara. ${ }^{5)}$

Kejahatan merupakan tindakan yang melanggar ketentuan dari hukum pidana, perbuatan ini sangatlah merugikan bagi masyarakat, dalam arti tidak sejalan dan atau menghambat untuk terjadinya kehidupan sosial dalam bermasyarakat dianggap baik dan adil. Banyaknya kasus-kasus tindak pidana terjadi saat ini, yang dikarenakan banyaknya faktor-faktor tertentu. Beberapa teori yang mengungkapkan sebab-sebab terjadinya kejahatan, misalnya teori ekologis, teori konflik kebudayaan dan teori ekonomi. Dalam negara modern hampir tiap perbuatan yang dicap sebagai kejahatan oleh sebagian besar penduduknya dirasakan sebagai pelanggaran kesusilaan, walaupun penilaiannya tidak seluruhnya sama. Terlepas dari perbedaan tersebut, terdapat perbedaan besar dalam memberikan penilaian tentang perbuatan yang dilarang, dari yang paling ringan sampai yang paling berat. White collar crime atau kejahatan kerah putih adalah kejahatan yang mengacu pada kejahatan orang-orang terpandang atau berstatus tinggi, contohnya korupsi.

Korupsi dalam bahasa Latin disebut Corruptio corruptus, dalam Bahasa Belanda disebut corruptie, dalam Bahasa Inggris disebut Corruption, dan dalam Bahasa Sansekerta yang tertuang dalam Naskah Kuni Negara

\footnotetext{
2010), hal.1.

${ }^{4)}$ R. Abdoel Djamali, Pengantar Hukum Indonesia Edisi Revisi, (Jakarta: Rajawali Pers,

${ }^{5)}$ Bambang Waluyo, Pidana dan Pemidanaan, (Jakarta: Sinar Grafika, 2008), hal.1.
} 
Kertagama arti harfiah corrupt menunjukan kepada perbuatan yang rusak, busuk, bejad, tidak jujur yang disangkutpautkan dengan keuangan. ${ }^{6}$

Tindak pidana korupsi sudah menjadi permasalahan yang mendarah daging di dalam masyarakat negara tercinta kita Indonesia, pertumbuhannya selalu bertumbuh dari tahun ke tahun, mulai dari jumlah kasus yang tertangkap ataupun dari jumlah kerugian itu sendiri serta dari segi kualitas moral yang dimiliki oleh bangsa Indonesia. Tindak pidana yang terjadi semakin terorganisir dan cakupan wilayahnya sudah meliputi seluruh kegiatan masyarakat yang ada.

Korupsi semakin marak terjadi di Indonesia, data statistik kriminal tahun 2017 menunjukkan kejahatan korupsi yang tercatat selama periode 2014-2016 berfluktuasi dengan kecenderungan meningkat. Pada tahun 2014 tercatat 814 kasus, tahun 2015 tercatat 1780, dan pada tahun 2016 tercatat 1318 kasus. ${ }^{7)}$ Hampir 80 persen kasus korupsi yang ditangani oleh Komisi Pemberantasan Korupsi (KPK) berasal dari sektor pengadaan barang dan jasa.

Mencegah supaya tidak terjadinya tindak pdana korupsi sangatlah penting. Hal ini dikarenakan tindak pidana korupsi merupakan salah satu tindak pidana yang sangat merugikan bagi seluruh masyarakat maupun pemerintah. Untuk mencegah supaya tidak terjadi tindak pidana korupsi, sebagaimana yang telah disebutkan didalam Kongres PBB mengenai "The Prevention of Crime and the Treatment of Offenders" pada Kongres PBB ke 6 tahun 1980 di Caracas, Venezuela mengatakan bahwa strategi pencegahan harus didasarkan pada penghapusan sebab-sebab dan kondisi-kondisi yang menimulkan kejahatan. ${ }^{8)}$

6) Marwan Effendy, Korupsi \& Strategi Nasional Pencegahan Serta Pemberantasannya, (Jakarta: Referensi, 2013), hal.13.

7) Badan Pusat Statistik, "Statistik Kriminal 2017”, www.bps.go.id, Diakses 30 Agustus 2018

8) Barda Nawawi Arief, Bungi Rampai Kebijakan Hukum Pidana (Perkembangan Penyusunan Konsep KUHP Baru), (Jakarta: Kencana, 2011), hal.47. 
Pengadaan barang dan jasa yang dilakukan melalui prosedur secara elektronik sudah pasti akan meingkatkan transparansi dan akuntabilitas, dan juga akan memicu terjadinya perkembangan akses pasar dan persaingan usaha yang sehat dan baik. Pengadaan barang dan jasa yang dilakukan melalui prosedur secara elektronik ini juga akan menigkatkan efisiensi dalam proses pengadaan, dan tentu saja melalui sistem secara elektronik akan mempermudah untuk melakukan kontrol terhadap pengadaan barang dan jasa tersebut. Dasar dari pembentukan Layanan Pengadaan Secara Elektronik (LPSE) adalah Pasal 111 Nomor 54 Tahun 2010 tentang pengadaan barang/jasa pemerintah.

Modus korupsi dalam pengadaan barang/jasa di sektor publik sebagaimana diungkapkan oleh Centre of International Crime Prevention (CIPC) dari UN Office for Drug Control and Crime Prevention (UNODCCP), antara lain: pemsalsuan (kecurangan), penyuapan (bribery), penggelapan (embez-zlement), pemberian komisi (commission), pemerasan (exortion) yang dilakukan oleh pejabat publik, pilih kasih (favoritien), penyalahgunaan wewenang (abuse of power), bisnis orang dalam (insider tranding), nepotisme (nepotism), dan sumbangan ilegal (illegal contribution). ${ }^{9)}$

Komisi Pemberantasan Korupsi (KPK) merupakan lembaga negara bantu yang diberikan tugas untuk melakukan pemberantasan korupsi secara profesional, intensif, dan berkesinambungan. Komisi ini mempunyai tugas dan wewenang melakukan koordinasi dan pengawasan, dan juga melakukan penyelidikan, penyidikan dan penuntutan sesuai dengan ketentuan perundangundangan yang ada. Komisi ini dimaksudkan untuk mendorong ketidak pastian dalam kasus korupsi, diimana Jaksa dan Polisi dianggap tidak bisa menyelesaikan tuntas kasus korupsi. ${ }^{10)}$

\footnotetext{
9) Purwosusilo, Aspek Hukum Pengadaan Barang Dan Jasa, (Jakarta: Kencana, 2014), hal.344-345.

10) Sudut Hukum, "KPK Merupakan Lembaga Negara Bantu”, www.suduthukum.com, 30 Mei 2017
} 
Pada dasarnya tujuan dari pendirian KPK bukanlah untuk mengambil lahan lembaga lain untuk memberantas korupsi. Melainkan untuk membantu lembaga tersebut agar pemberantasan korupsi menjadi lebih efektif, KPK memiliki tugas untuk melakukan koordinasi dengan instansi yang berwenang melakukan pemberantasan tindak pidana korupsi. Penjelasan undang-undang menyebutkan peran KPK sebagai trigger mechanism, yang berarti mendorong atau sebagai stimulus agar upaya pemberantasan korupsi oleh lembagalembaga yang telah ada sebelumnya menjadi lebih efektif dan efisien.

KPK ketika melaksanakan tugasnya harus memiliki lima acuan sebagai pedoman, antara lain, kepastian dalam melaksanakan pedoman, transparan, memiliki sifat yang akuntabilitas, mengutamakan kepentingan publik, dan proporsionalitas. KPK memiliki tanggung jawab yang besar kepada masyarakat luas dan harus memberikan lamporannya secara terbuka, lengkap, berkala kepada Lembaga Eksekutif dalam hal ini Presiden, Legislatif dalam hal ini DPR, dan BPK.

KPK merupakan organisasi yang dipimpin oleh pimpinan KPK yang terdiri dari lima orang, seorang ketua merangkap anggota dan empat orang wakil ketua yang merangkap sebagai anggota juga, pimpinan KPK tersebut adalah pejabat negara yang terdiri dari unsur pemerintahan, dan unsur masyarakat yang turut serta dalam melaksanakan organisasi KPK. pimpinan KPK dalam menjalankan jabatannya memiliki masa jabatan selama 4 tahun dan dapat diangkat sekali lagi untuk melaksanakan jabatannya kembali. Dalam melaksanakan pengambilan keputusan, keputusan tersebut harus bersifat kolektif kolegial.

Struktur kepempinan KPK membawahi 4 divisi bidang, yang antara lain tersusun atas bidang pencegaha, bidang penindakan, bidang informasi dan data, serta bidang pengawasan internal dan pengaduan masyarakat. Yang mana tiap tiap bidang tersebut dipimpin oleh seorang deputi KPK yang dibantu oleh Sekretariat Jenderal yang dalam hal ini dipimpin oleh Seorang Sekretaris Jendreal yang diangkat dan berhentikan langsung oleh lembaga 
eksekutif yaitu presiden, namun pertanggungjawabannya tetap kepada pimpinan KPK.

Struktur dan organisasi KPK diatur secara runtun demi agar masyarakat dapat ikut serta dalam aktivitas dan kegiatan yang dilakukan oleh KPK. Dalam pelaksanaan operasional, KPK mengangkat pegawai yang direkrut sesuai dengan kompetensi yang diperlukan ${ }^{11)}$

Menurut apa yang dibahas didalam Pasal 6 Undang-Undang Nomor 30 Tahun 2002 tentang Komisi Pemberantasan Korupsi menyebutkan bahwa terdapat lima tugas dari Komisi Pemberantasan Korupsi yang harus dilaksanakan, yaitu koordinasi dengan instansi yang terkait untuk melakukan pemberantasan tindak pidana korupsi, supervisi terhadap instansi yang berwenang melakukan pemberantasan tindak pidana korupsi, melakukan penyidikan, penyidikan, dan penuntutan terhadap tindak pidana korupsi, pencegahan dan melakukan monitoring terhadap penyelenggaraan pemerintah negara.

Berdasarkan latar belakang diatas judul penelitian ini adalah "Kajian Yuridis Fungsi Pencegahan Komisi Pemberantasan Korupsi dalam Pemberantasan Tindak Pidana Korupsi Pengadaan Barang dan Jasa Secara Elektronik di Provinsi DKI Jakarta”.

\section{B. Permasalahan}

Berdasarkan latar belakang diatas, dapat dikemukakan rumusan masalah dari penelitian ini adalah bagaimana kajian yuridis fungsi pencegahan Komisi Pemberantasan Korupsi dalam pemberantasan tindak pidana korupsi pengadaan barang dan jasa secara elektronik di provinsi DKI Jakarta?

\section{Pembahasan}

\section{A. Komisi Pemberantasan Korupsi}

1. Tinjauan Umum Mengenai Komisi Pemberantasan Korupsi (KPK)

\footnotetext{
${ }^{11)}$ Komisi Pemberantasan Korupsi, "Tentang KPK”, www.kpk.go.id,
} 
Komisi Pemberantasan Korupsi adalah lembaga negara bantu yang dalam melaksanakan tugas dan wewenangnya dalam memberantas tindak pidana korupsi bersifat independen dan tidak terpengaruh kekuasaan manapun. $^{12)}$

Konsep dari pembuatan Komisi Pemberantasan Korupsi (KPK) sejak pertama kali dicetuskan adalah dalam perspektif transisi penegakan hukum, bukan untuk dipermanenkan. Lembaga ini dibentuk berdasarkan Undang-Undang Nomor 30 Tahun 2002 tentang Komisi Pemberantasan Tindak Pidana Korupsi.

Penegakan hukum yang dilakukan untuk melakukan pemberantasan dan pembinasaan tindak pidana korupsi yang masih menggunakan cara metode klasik yang mana hanya sebatas menggunakan media pemberantasan berupa kewenangan kepolisian dan jaksa yang mana sejauh ini menunjukan ketidakefektifan dalam upaya pemberantasannya. Oleh sebab itu maka diperlukan sebuah cara khusus yang memiliki sebuah inovasi khusus dalam penegakan hukum yang luar biasa melalui pembentukan sebuah instansi khusus yang memiliki kekuasaan otoritas khusus, independen, bebas dan mandiri yang mana terlepas dari ekkuaaan apapun itu dalam upaya pembinasaan tindak pidana korupsi, demi tercapainya pelaksanaan pemberantasan yang efektif, optimal, intensif, profesional dan terintegritas. ${ }^{13)}$

2. Tugas dan Wewenang dari KPK

a. Tugas

1) Melakukan kerja sama dengan lembaga atau pihak lain yang terkait dan memiliki wewenang untuk melakukan pemberantasan tindak pidana korupsi;

\footnotetext{
${ }^{12)}$ Ermansjah Djaja, Memberantas Korupsi Bersama KPK, (Jakarta: Sinar Grafika, 2010),
} hal.254.

${ }^{13)}$ Ibid., hal.255. 
2) Melaukan pengawasan kepada lembaga yang berwenang melakukan pemberantasan tindak pidana korupsi;

3) Melakukan penyelidikan, penyidikan, dan penuntutan terhadap tindak pidana korupsi;

4) Melakukan tindakan-tindakan mencegah tndak pidana korupsi;

5) Melakukan controlling kepada penyelenggara pemerintahan negara. ${ }^{14)}$

b. Wewenang

1) Bekerja sama dalam proses penyelidikan, penyidikan, dan penuntutan tindak pidana korupsi;

2) Membuat suatu sistem pelaporan untuk kegiatan pemberantasan tindak pidana korupsi;

3) Mengambil informasi tentang kegiatan pemberantasan tindak pidana korupsi kepada lembaga terkait;

4) Melakukan tatap muka dengan istansi yang berwenang melakukan pemberantasan tindak pidana korupsi dan;

5) Meminta laporan kepada lembaga yang berhubgungan dengan pencegahan tindak pidana korupsi. ${ }^{15}$

3. Kewajiban KPK

a. Melakukan perlindungan kepada saksi ataupun pelapor yang memeritahukan laporan ataupun memberikan bocoran mengenai kasus tindak pidana korupsi yang terjadi;

b. Melakukan koordinasi dengan instansi yang terkait untuk melakukan pemberantasan tindak pidana korupsi;

c. Membuat laporan tahunan dan dibublikasikan kepada Presiden Republik Indonesia, Dewan Perwakilan Rakyat Republik Indonesia, dan Badan Pemeriksa Keuangan;

d. Menjalankan sumpah jabatan;

\footnotetext{
14) Indonesia, Undang Undang Nomor 20 Tahun 2002 Tentang Komisi Pemberantasan Korupsi Pasal 6.

${ }^{15)}$ Indonesia, Undang Undang Nomor 20 Tahun 2002 Tentang Komisi Pemberantasan Korupsi Pasal 7.
} 
e. Menjalankan tugas, tanggung jawab, dan wewenangnya berdasarkan asas-asas sebagaimana dimaksud dalam Pasal 5. ${ }^{16)}$

\section{B. Tindak Pidana Korupsi}

1. Tinjauan Umum Mengenai Tindak Pidana Korupsi

Tindak pidana adalah tindakan yang cuma bisa dikenai hukuman, jika tindakan itu didahului oleh ancaman hukuman di undang-undang yang berlaku. ${ }^{17)}$ Tindak pidana korupsi adalah alah satu perbuatan yang dilakukan dengan tujuan untuk mengambil satu atau lebih keuntungan yang dilakukan dengan cara yang tidak resmi dengan mengunakan hak-hak dari pihak lain secara salah menggunakan jabatannya atau karakternya untuk mendapatkan suatu keuntungan untuk dirinya sendiri atau orang lain, bersamaan dengan kewajiban dan hak-hak pihak lain. ${ }^{18)}$ Definisi korupsi dapat dipandang dari berbagai aspek, bergantung dari disiplin ilmu yang menjadi titik pijak. Dari segi bahasa, sosiologi, antropologi, ekonomi, dan hukum dapat menghasilkan definisi yang berbeda mengenai korupsi. Definisi atau batasan korupsi ini menjadi penting karena menjelaskan perbuatan yang dianggap tercela atau melawan hukum (wederrechtelijkheid) di antara perbuatan-perbuatan melawan hukum lainnya. ${ }^{19)}$ Tindak pidana korupsi telah diatur di dalam Undang-Undang Nomor 31 Tahun 1999 tentang Pemberantasan Tindak Pidana Korupsi Jo Undang-Undang Nomor 20 Tahun 2001 tentang perubahan atas UndangUndang Nomor 31 Tahun 1999.

2. Berbagai Persepsi Penyebab Terjadinya Korupsi

a. Aspek Individu Pelaku Korupsi

\footnotetext{
${ }^{16)}$ Indonesia, Undang Undang Nomor 20 Tahun 2002 Tentang Komisi Pemberantasan Korupsi Pasal 15.

17) van Apeldoorn, Pengantar Ilmu Hukum, (Jakarta: Pradnya Paramita, 2011), hal.324.

${ }^{18)}$ Marwan Effendy, Sistem Peradilan Pidana Tinjauan Terhadap Beberapa Perkembangan Hukum Pidana, (Jakarta: Referensi, 2012), hal.82.

19) Marwan Effendy, Op.Cit., hal.12.
} 
Jika diamati dari segi sipelaku tindak pidana korupsi, penyebab dia berpikiran dan akhirnya melakukan korupsi bisa berupa pikiran dari dalam hatinya, yang dapat pula dikatakan sebagai keinginan, niat, atau kesadarannya untuk melakukan hal tersebut. Faktor atau penyebab orang ingin korupsi antara lain adalah:

1) Bawaan manusia yang tidak pernah puas;

2) Sikap yang tidak bisa menahan napsu;

3) Penghasilan yang tidak sesuai dengan kebutuhan;

4) Hal-hal yang penting untuk hidup;

5) Pemborosan;

6) Tidak ingin mengerjakan apapun;

7) Tidak memiliki unsur-unsur religius sama sekali. ${ }^{20)}$

b. Aspek Organisasi

Organisasi yang dimaksud adalah organisasi dalam arti yang luas, termasuk didalamnya mengenai kepengurusan mengenai lingkungan yang ada disekitar masyarakat. Organisasi bisa menjelma menjadi viktim dari korupsi ataupun menjadi tempat terjadinya korupsi yang mana kecenderungan memberikan kesempatan dan peluang terciptanya tindak pidana korupsi itu sendiri. Jika organisasi sama sekali tidak membuka sebuah kesempatan bagi oknum oknum tertentu untuk melakukan perbuatan korupsi, maka tentunya akan meminimalisir korupsi yang ada di masyarakat akibat organisasi tersebut. Adapun beberapa faktor yang menyebabkan organisasi menjadi unsur pendukung terjadinya tindak pidana korupsi, antara lain sebagai berikut: Sebab mengapa organisasi menjadi faktor seseorang untuk melakukan tindak pidana korupsi diantaranya;

1) Pimpinan memberi contoh yang buruk;

2) Tidak terdapat budaya yang baik di dalam organisasi;

3) Sistem pemerintahan yang tidak terpercaya;

4) Sistem manajemen yang buruk;

\footnotetext{
${ }^{20)}$ Marwan Effendy, Op.Cit., hal.27.
} 
5) Manajemen cenderung menutupi korupsi dalam organisasinya. ${ }^{21)}$

c. Aspek Masyarakat Tempat Individu dan Organisasi Berada

1) Norma-norma yang ada di masyarakat mendukung untuk terjadinya tindak pidana korupsi;

2) Masyarakat tidak sadar kalau yang dirugikan dari korupsi adalah dirinya sendiri;

3) Masyarakat tidak sadar kalau mereka juga terlibat korupsi;

4) Masyarakat sama sekali tidak memiliki tingkat kesadaran yang cukup bhwa, tindakan pencegahan untuk melakukan pemberantasan korupsi akan berjalan apabila adanya andil masyrakat untuk mewujudkannya;

5) Masyarakat milenial indonesia sudah harus berhadapan dengan maraknya tindakan korupsi yang terjadi sejak mereka dilahirkan;

6) Penyalahartian pengertian-pengertian dalam budaya bangsa Indonesia.

d. Aspek Peraturan Perundang-Undangan

Korupsi mudah timbul karena adanya kelemahan di dalam perundang-undangan, yang mencakup:

1) Adanya undang-undang yang tidak jelas yang menguntungkan salah satu pihak;

2) Kualitas peraturan perundang-undangan yang tidak baik;

3) Tidak efektifnya Judicial Review oleh Mahkamah Agung dan Mahkamah Konstitusi;

4) Aturan yang tidak di sosialisaikan;

5) Sanksi yang ada di dalam aturan perundang-undangan terlalu ringan yang membuat para oknum tidak merasa takut untuk melakukan tindak pidana korupsi;

6) Penerapan hukuman atau sanksi yang tidak netral;

7) Lemahnya bidang evaluasi dan revisi pada peraturan perundangundangan. $^{22)}$

\footnotetext{
${ }^{21)}$ Ibid., hal.28.
} 


\section{Pengadaan Barang dan Jasa}

1. Tinjauan Umum Mengenai Pengadaan Barang dan Jasa

Pengadaan Barang dan Jasa Pemerintah yang biasa disebut dengan Pengadaan Barang dan Jasa adalah aktivitas untuk mendapatkan Barang atau Jasa dari Kementerian atau Lembaga atau Satuan Kerja Perangkat Daerah dan atau Institusi lainnya yang prosesnya dimulai sejak perencanaan kebutuhan sampai berakhirnya seluruh aktivitas untuk mendapatkan Barang atau Jasa. ${ }^{23)}$ Penyedia Barang atau Jasa adalah badan usaha atau orang perorangan yang menyediakan Barang ataupun bisa Pekerjaan Konstruksi atau Jasa Konsultansi dan Jasa lainnya. Maksud dari pengadaan barang dan jasa adalah untuk mendapatkan barang atau jasa dengan harga atau Budget yang di sesuaikan dengan kuantias, kualitas serta prosesnya yang tepat waktu.

Pengadaan barang dan jasa dibiayai oleh Anggaran Pendapatan Belanja Negara atau Daerah yang biasa disebut APBN/D, biasanya $\mathrm{APBD} / \mathrm{N}$ tersebut selalu naik tiap tahunnya. Begitu juga dengan komponen belanjaan APBD/N yang berupa belanja modal atau investasi atau belanja langsung, yang pelaksanaannya dilakukan melalui pengadaan barang/jasa.

Tujuan dari pengadaan barang dan jasa sebenarnya adalah usaha dari pihak pembeli barang atau jasa (pemerintah) untuk mendapatkan atau mewujudkan barang dan jasa yang diinginkannya, maka semua pihak baik pembeli ataupun penyedia harus mengikuti pada aturan yang sudah dibuat untuk melakukan proses pengadaan barang dan jasa tersebut. ${ }^{24)}$

2. Masalah Pada Pengadaan Barang dan Jasa

\footnotetext{
${ }^{22)}$ Ibid., hal.29.

${ }^{23)}$ Indonesia, Peraturan Presiden Nomor 54 Tahun 2010 Tentang Pengadaan Barang dan Jasa Pasal 1.

${ }^{24)}$ Abu Samman Lubis, “Aspek Hukum Dalam Pengadaan Barang Dan Jasa Pemerintah”, www.bppk.kemenkeu.go.id, 11 Januari 2011
} 
Pada pelaksanaan pengadaan barang dan jasa pemerintah, sering terjadi masalah salah satunya adalah korupsi pada pengadaan barang dan jasa. Pengadaan barang dan jasa yang dilakukan oleh pemerintah sering kali dianggap sebagai lahan yang "basah" karena sering kali praktek korupsi pada saat mulai dari penganggaran sampai ke pelaksanaan dari pengadaan barang dan jasa itu sendiri. Masih banyaknya korupsi pada pengadaan barang dan jasa yang dilakukan oleh pemerintah karena masih kurangnya pengawasan secara ketat. Selain itu faktor lain yang menyebabkan masih maraknya atau berkembangnuya korupsi dalam pengadaan barang dan jasa adalah kurangnya integritas para pelaksana maupun orang orang yang melakukan ataupun merencanakan pengadaan barang dan jasa ini. Masalah pada pengadaan barang dan jasa pemerintah tidak hanya korupsi, masih banyak masalah pada pengadaan barang dan jasa pemerintah misalnya kualitas barang ataupun jasa yang tidak sesuai dengan apa yang telah direncanakan ataupun masalah ketidaktepatan waktu yang diperlukan untuk menyelesaikan satu proyek. Hal ini akan berakibat pada tidak sesuainya apa yang telah direncanakan dan apa yang telah dilakukan dalam pengadaan barang dan jasa yang dilakukan pemerintah, dan pastinya akan menimbulkan kerugian maupun secara keuangan maupun kerugian secara waktu.

\section{Sistem Pengadaan Secara Elektronik (SPSE)}

1. Tinjauan Umum Mengenai Sistem Pengadaan Secara Elektronik (SPSE)

Sistem Pengadaan Secara Elektronik (SPSE) merupakan aplikasi $e$ procurement yang dikembangkan oleh Direktorat -Procurement Lembaga Kebijakan Pengadaan Barang/Jasa Pemerintah (LKPP) untuk digunakan oleh Layanan Pengadaan Secara Elektronik (LPSE) di seluruh Kementerian/Lembaga/Satuan Kerja Perangkat Daerah/lnstitusi Lainnya K/L/D/I. Aplikasi ini dikembangkan dengan semangat efisiensi nasional sehingga tidak memerlukan biaya lisensi, baik lisensi SPSE itu sendiri maupun perangkat lunak pendukungnya. Sistem Pengadaan Secara Elektronik (SPSE) dikembangkan oleh Lembaga Kebijakan Pengadaan 
Barang dan Jasa Pemerintah (LKPP) yang bekerja sama dengan:

1. Lembaga Sandi Negara (Lemsaneg) untuk melakukan atau fungsi enkripsi dokumen

2. Badan Pengawasan Keuangan dan Pembangunan (BPKP) untuk sub sistem audit. $^{25)}$

\section{E. Kajian Yuridis Fungsi Pencegahan KPK Dalam Melakukan Pencegahan} Tindak Pidana Korupsi Pengadaan Barang dan Jasa Secara Elektronik di Provinsi DKI Jakarta

Korupsi merupakan kegiatan dimana sesorang yang mempunyai wewenang melakukan perbuatan yang curang dengan menggunakan wewenang yang ia miliki untuk mendapatkan keuntungan untuk orang sekeliling maupun dirinya sendiri. Korupsi di indonesia sebenarnya sudah ada sejak lama, tetapi karena adanya pengaruh dari pemerintah pada zaman dulu mengakibatkan korupsi menjadi hal yang tidak diketahui oleh masyarakat luas. Karena tidak diketahui oleh masyarakat, maka korupsi semakin berkembang di kalangan orang-orang yang memiliki kewenangan saja, dan lama kelamaan menjadi suatu hal yang dianggap biasa. Indonesia menuduki angka korupsi salah satu yang tertinggi dan sudah sangat mengkhawatirkan.

Suburnya ladang korupsi di Indonesia mendorong pergerakan pemberantasan korupsi. Namun pemberantasan korupsi di Indonesia belum menunjukan titik terang. Hal ini tentu menimbulkan kekhawatiran akan keseriusan pemerintah dalam memberantas tindak pidana korupsi apalagi dengan masa sekarang dimana adanya lembaga untuk mengatasi atau memberantas tindak pidana korupsi.

Selain itu, pemberantasan korupsi yang dilakukan melalui cara lama sejauh ini telah terlihat mengalami macam macam hambatan. Oleh karena itu sudah waktunya dibuat suatu badan yang mempunyai kekuatan yang lebih besar dibanding dengan badan atau lembaga yang lama dan netral untuk

\footnotetext{
${ }^{25)}$ Lembaga Kebijakan Pengadaan Barang/Jasa Pemerintah, “Tentang Kami”, www.lpse.lkpp.go.id.
} 
melakukan tindakan maupun pengawasan untuk memberantas mapun mencegah terjadinya tindak pidana korupsi. Lembaga ini juga harus profesional dalam melakukan tindakan memberantas korupsi maupun mencegahnya.

Lembaga yang diharapkan bisa mengurangi angka kejahatan korupsi adalah Komisi Pemberantasan Korupsi atau yang biasa kita kenal dengan anama KPK. Dalam bagian konsideran huruf a dan huruf b Undang-Undang Nomor 30 Tahun 2002 tentang Komisi Pemberantasan Tindak Pidana Korupsi disebutkan, kalau tujuan dari dibentuknya komisi ini adalah bentuk dari semakin meluasnya dan smakin banyaknya korupsi di tanah air ini. Korupsi sangatlah merugukan dari segi keuangan negara dimana yang seharusnya uang negara tersebut untuk pembangunan negara malah masuk kedalam kanting orang yang tidak bertanggung jawab nyang memiliki wewenang ataupun jabatan untuk melakukan tindakan tersebut. Usaha pemerintah untuk menangulani korupsi selama ini tidaklah menunjukan hasil yang baik, maka dibentuklah lembaga ini untuk bertujuan bisa mengurangi persentasi angka korupsi di tanah air.

Atas dasar itu, dapat diketahui bahwa tujuan pembentukan KPK adalah untuk mengoptimalkan pemberantasan tindak pidana korupsi yang sulit diharapkan terwujudnya jika terus mengandalkanlembaga penegak hukum yang telah ada. Hal ini disebabkan karena pada kenyataannya aparat penegak hukum itu sendiri sering kali justru terlibat dalam praktik korupsi atas perkara yang mereka tangani sendiri. Pemberian wewenang yang sangat besar kepada KPK memang dikhawatirkan dapat melahirkan masalah tumpang tindih tugas dan kewenangan dengan aparat lain.

Usaha yang dilakukan untuk menanggulangi korupsi di Indonesia harus dimulai dengan pemahaman akan keberadaan korupsi itu sendiri. Kondisi yang ada dilapangan pada saat ini menunjukan bahwa masih adanya ketidak sepahaman antara masyarakat dan pemerintah sebagai upaya untuk penegakan dan penanggulangan korupsi. Hal inilah yang disebabkaan akibat dari ketidak selarasan cara pandang dan kepentingan. Oleh karena itu pengenalan dan 
penjelasan mengenai keberadaan korupsi sangatlah penting untuk mengatasi urgensi dalam memandang korupsi sebagai hal yang membahayakan yang dapat merusak kehidupan bermasyarakat dan bernegara.

Salah satu unsur yang menjadi faktor utama untuk mengatasi dan berperan penting dalam menangani kasus korupsi adalah integritas penegak hukum. Akan tetapi penyebab banyaknya koruupsi bukan dari faktor integritas para penegak hukum yang lemah saja. Kelemahan ini juga dari fakror hukum pidananya. sistem hukum pidana dibagi menjadi tiga unsur, yaitu Substance yang menyangkut materi hukumnya, Structure yang menyangkut struktur hukum yang dalam hal ini adalah sistem peradilan pidana (Criminal Justice System) dan Culture atau kultur (budaya) hukum masyarakat dalam konteks penegakan hukum terhadap tindak pidana korupsi. Faktor penegak hukum juga memegang peran besar dalam pemberantasan tindak pidana korupsi, bahkan juga menilai dari segi efektifitas penegak hkum tindak pidana korupsi.

Tindakan penegakan hukum adalah tindakan yang dilakukan oleh aparat yang berwenang kepada orang atau lembaga ataupun pelaku yang telah melakukan tindak pidana korupsi. Tindakan hukum ini tidak boelh memihak dan diharuskan netral, siapapun yang disangka maupun telah terbukti melakukan tindak pidana korupsi harus diproses sesuai dengan aturan.

KPK dipimpin oleh pimpinan KPK yang terdiri atas lima orang, seorang ketua merangkap anggota dan empat orang wakil ketua merangkap anggota. Kelima pimpinan KPK tersebut merupakan pejabat negara, yang berasal dari unsur pemerintahan dan unsur masyarakat. Pimpinan KPK memegang jabatan selama empat tahun, dan dapat dipilih kembali hanya untuk sekali masa jabatan. Pimpinan KPK membawahkan empat bidang, yang terdiri atas bidang pencegahan, bidang penindakan, informasi dan data, serta pengawasan internal dan pengaduan masyarakat. Masing-masing bidang tersebut dipimpin oleh seorang deputi. KPK juga dibantu sekretaris jenderal yang dipimpin oleh sekretaris jenderal yang diangkat dan diberhentikan oleh Presiden Republik Indonesia, namun bertanggung jawab kepada pimpinan KPK. 
Mengapa pengadaan barang dan jasa yang diadakan oleh pemerintah sangatlah rawan terjadinya korupsi atau suap yang disebabkan oleh penyalahgunaan wewenang? Hal ini dikarenakan banyak oknum oknum yang ingin memperoleh keuntungan dengan cara curang yaitu dengan cara memilih tender kepada orang orang tertentu. Tidak melalui lelang yang netral karena banyak dari mereka sudah saling mengenal, supaya mempermudah mendapatkan proyek pengadaan barang dan jasa. Korupsi ini merupakan salah satu penyalahgunaan wewenang aparat negara, yang memiliki jabatan atas pengadaan barang dan jasa khususnya secara elektronik. Walaupun maksud dari pengadaan barang dan jasa secara elektronik adalah untuk meminimalisisr terjadinya korupsi dalam pengadaan barang dan jasa, tetap saja masih memeiliki celah atau kesempatan yang dapat memicu terjadinya korupsi dalam pengadaan barang dan jasa secara elekronik. Mengapa masih terjadi korupsi walaupun pengadaan barang dan jasa sudah melalui proses secara elektronik? Hal ini dikarenakan kebanyakan orang-orang yang terlibat dalam prosedur pengadaan barang dan jasa secara elektronik sudah saling mengenal antara satu sama lain. Baik dari sisi pemerintah sebagai pemilik proyek maupun sisi orang yang memberikan barang ataupun jasa. Karena sudah saling mengenal antara satu dengan lainnya, maka terjadilah tawar menawar harga untuk dapat memenangkan tender. Walaupum sudah dilakukan secara elektronik atau disebut e-tenderring tentu saja sistem ini masih dikendalikan oleh sumber daya manusia dan tidak sepenuhnya sistem ini dapat berjalan sendiri. Dan tentunya masih juga di kontrol oleh manusia, dimana hal ini berpotensi terjadinya kecurangan dalam membuka ataupun menutup sistem pengadaan secara elektronik tersebut. Tentu saja melalui sitem e-tenderring ini tidak serta merta menghilangkan korupsi pada pengadaan barang dan jasa oleh pemerintah, tetapi sudah mengalalami perkembanagan dimana untuk masuk kedalam sistem tentunya sudah memiliki syarat atau standar tertentu yang cukup ketat yang harus sesuai dengan peraturan.

Dampak dari tidak dilaksanakannya atau dimaksimalkannya fungsi pencegahan pada KPK berada pada adanya kerugian negara yang sangat besar 
yang diakibatkan oleh korupsi yang diperbuat oleh para oknum-oknum tertentu. Oknum-oknum tersebut seringkali memakai celah-celah yang ada, seperti peraturan-peraturan yang belum diatur secara jelas dan detail dalam prosedur pengadaan barang dan jasa secara elektronik. Apabila tahap pencegahan tersebut berjalan secara efektif maka hal-hal seperti kerugian negara, keresahan masyarakat, maupun persaingan usaha yang tidak sehat tidak harus terjadi. Begitu juga dengan angka terjadinya korupsi khususnya pada pengadaan barang dan jasa secara elektronik di provinsi DKI Jakarta.

\section{F. Analisis Fungsi Pencegahan Komisi Pemberantasan Korupsi}

Ada empat fungsi pokok lembaga pemberantasan korupsi menurut standar PBB, yaitu pertama fungsi pengembangan kebijakan, riset, monitoring dan koordinasi. Kedua fungsi pencegahan korupsi dalam struktur kekuasaan. Ketiga fungsi pendidikan dan penyadaran, dan keempat fungsi investigasi dan penyidikan. Oleh karena KPK mengadopsi model kelembagaan multipurpose menurut standar normatif PBB, yaitu pencegahan dan penindakan tindak pidana korupsi, menjadi relevan jika standar PBB tersebut dipakai untuk memotret kiprah dan kinerja KPK.

Sejak berdirinya KPK, praktik korupsi dalam struktur kekuasaan negara secara kuantitatif bukannya menurun, malah semakin banyak. Penindakan para koruptor secara tegas yang seharusnya menimbulkan efek positif bagi pencegahan korupsi. Dengan kewenangan dari KPK yang demikian besar dan luas, KPK belum bisa membuat oknum-oknum pejabat negara lainnya menjadi takut untuk melakukan korupsi.

Problem lanjutan dari ketimpangan pelaksanaan fungsi pencegahan korupsi dalam struktur kekuasaan negara adalah adanya mekanisme politik dalam praktik perpolitikan Indonesia, yang memberi kewenangan kepada Dewan Perwakilan Rakyat Republik Indonesia melalui anggota-anggota Komisi III DPR RI yang notabene adalah perwakilan dari partai-partai politik, untuk turut serta menentukan proses rekrutmen kepemimpinan di KPK. Mekanisme semacam ini menimbulkan kerawanan politik bagi kepemimpinan di tubuh KPK, sehingga dugaan-dugaan adanya konsensi politik tertentu 
antara KPK dan DPR tidak dapat dihindarkan. Salah satu indikatornya adalah upaya memastikan pengawasan yang efektif terhadap keuangan partai-partai politik tidak berjalan sehingga transparansi dana kampanye misalnya, masih terus menjadi problem serius.

Sebenarnya ada sangat banyak sekali faktor faktor yang membuat korupsi semakin bantak ataupun marak terjadi di kehidupan di indonesia ini. Salah satu faktornya adalah masih banyaknya orang-orang atau masyarakat yang tidak memahami apa itu korupsi. Sepeti contoh uang pelicin atau sogok, itu masuk kedalam contoh korupsi akan tetapi masih banyak masyarakat yang tidak memahami akan hal itu merupakan ssalah satu contoh dari tindak pidana korupsi. Karena itu masuk kedalam penyogokan. Faktor lainnya masih banyak masyarakat indonesai yang tidak melek atau sadar hukum, dimana masih banyaknya masyarakat indonesia yang tidak memahami hukum sama sekali. Jadi menurut masyarakat yang tidak mengetahui itu sama sekali menggangap sogok atau korupsi tersebut dapat mempercepat atau menyelesaikan masalah secara cepat, padahal tidak malah akan menimbulkan masalah lain yang baru. Lalu ada faktor dimana situasi di Indonesia ini sangatlah memungkinkan untuk terjadinya tindak pidana korupsi kenapa ini maasih terjadi? Hal ini dikarenakan koripsi sudah masuk kedalam kehidupan bermasyarakat sampai keorgan terkecil sekalipun. Contohnya sogok menyogok sudah menjadi hal yang biasa di dalam kehidupan bermasyarakat maupun bernegara. Korupsi tidak harus dalam jumlah yang besar dengan nominal uang yang banyak. Korpsi seperti uang cepat ataupun uang pelicin sudah masuk kedalam kategori korupsi tetapi tidak mauk kedalam kategori yang berat. Faktor lainnya juga karena faktor jabatan, karena masih banyaknya orang-orang yang memerlukan uang untuk mendapatkan jabatan, maka dari itu banyak yang mengiinginkan uang atau modal tersebut kembali dengan cara yang kotor yang tidak sesuai dengan norma ataupun aturan yang sudah ada. Salah satunya dalah korupsi ini, dengan cara menerima suap dan uang lainnya untuk mengembalikan modal yang sudah dikeluarkan untuk mendapatkan jabatan tersebut. 
Fungsi pencegahan pada Komisi Pemberantasan Korupsi (KPK) telah diatur didalam Undang-Undang Nomor 30 Tahun 2002 tentang Komisi Pemberantasan Korupsi pada Pasal 6 huruf d, yang menyebutkan bahwa KPK dapat melakukan tindakan-tindakan pencegahan tindak pidana korupsi.

Deputi Bidang Pencegahan Komisi Pemberantasan Korupsi Republik Indonesia atau cukup disebut Deputi Bidang Pencegahan Komisi Pemberantasan Korupsi adalah unit eselon 1 di Komisi Pemberantasan Korupsi yang mempunyai tugas menyiapkan rumusan kebijakan dan melaksanakan kebijakan di bidang pencegahan tindak pidana korupsi. Deputi Bidang Pencegahan dipimpin oleh Deputi Bidang Pencegahan dan bertanggungjawab atas pelaksanaan tugasnya kepada Pimpinan KPK.

Presiden Joko Widodo juga telah mengeluarkan Peraturan Presiden Nomor 54 Tahun 2018 tentang Strategi Pencegahan Korupsi. Peartutan Presiden ini bertujuan untuk mencegah terjadinya korupsi di indonesia yang sudah semakin menjerat kedalam segala aspek. Peraturan Presiden ini khususnya diperuntukan untuk mencegah korupsi yang dilakukan oleh organ pemerintahan maupun lembaga lembaga lain. Peraturan presiden ini juga merupakan suatu wujud nyata presiden Joko Widodo dan pemerintah Indonesia untuk melakukan tindakan pencegahan tindak pidana korupsi. Tenu saja Komisi Pemberantasan Korupsi sebagai lembaga anti korupsi juga memegang andli yang sangat besar dimana jika dilihat secara seksama perarturan peresiden ini merupakan peraturan yang bisa dibilang mendukung langkah Komisi Pemberantasan Korupsi dalam melakukan tindakan pencegahan korupsi di Indonesia. Korupsi di Indonesia sudah masuk kedalam presentase yang membahayakan dimana sudah menjalar kemana-mana sampai keorgan terkecil pemerintahan sekalipun. Komisi Pemberantasan Korupsi tentunya harus bekerja keras untuk melakukan tindakan pemberantasan korupsi khususnya daam tindakan pencegahan. Komisi Pemberantasan Korupsi juga harus senantiasa melakukan pengawasan secara terus menerus kepada lembaga atau organ-organ pemerintahan yang rawan untuk terjadinya tindak pidana korupsi. 
Menurut Peneliti, peraturan mengenai fungsi pencegahan KPK sebagai lembaga yang salah satu tugasnya adalah untuk mencegah terjadinya tindak pidana korupsi sudah cukup jelas. Secara umum fungsi pencegahan yang dirumuskan dalam undang-undang KPK telah diatur. Akan tetapi untuk penerapan dari fungsi pencegahan tersebut masih kurang. Hal ini dikarenakan masih banyak terjadi korupsi dalam pengadaan barang dan jasa.

\section{PENUTUP}

\section{A. Kesimpulan}

Dari analisis diatas, dapat diambil kesimpulan bahwa KPK adalah organisasi atau lembaga yang independen dan tidak terpengaruh dari pihak penguasa manapun yang berwenang untuk melakukan pencegahan dan pemberantasan tindak pidana korupsi. Fungsi pencegahan KPK telah diatur di dalam Undang-Undang Nomor 30 Tahun 2002 Tentang Komisi Pemberantasan Tindak Pidana Korupsi pada pasal 6 huruf d, yang mengatakan bahwa KPK mempunyai wewenang untuk melakukan tindakantindakan untuk mencegah terjadinya tindak pidana korupsi. KPK merupakan lembaga negara yang memiliki mandat untuk melakukan tindakan-tindakan pemberantasan korupsi, maupun tindakan pencegahan tindak pidana korupsi. Pada penerapannya, KPK memiliki divisi Bidang Pencegahan. Tugas dari Bidang Pencegahan adalah untuk melaksanakan tindakan-tindakan pencegahan sebagaimana yang telah diatur didalam Pasal 6 huruf d UndangUndang Nomor 30 Tahun 2002 Tentang Komisi Pemberantasan Tindak Pidana Korupsi, dan diperdalam di pasal 5 Peraturan KPK Nomor 15 Tahun 2015 tentang Organisasi dan Tata Kerja Komisi Pemberatantasan Korupsi.

Pemerintah Republik Indonesia terus berupaya melakukan terobosan terobosan baru guna menanggulangi tindak pidana korupsi. Hal ini dibuktikan dengan diluncurkannya Peraturan Presiden Nomor 54 Tahun 2018 mengenai Strategi Pencegahan Korupsi, dimana tujuan dari dibuatnya Peraturan Presiden ini melalui Presiden Joko Widodo untuk mencegah terjadinya tindak pidana korupsi yang semakin marak khususnya dalam korupsi pengadaan barang dan jasa secara elektronik. 


\section{B. Saran}

Berdasarkan pembahasan diatas, KPK seharusnya dapat mempertahankan independensinya dari segala pihak manapun dalam melakukan tugas dan wewenangnya tersebut supaya KPK dapat melakukan tugasnya secara maksimal. Walaupun Dewan Perwakilan Rakyat melalui anggota-anggota Komisi III Dewan Perwakilan Rakyat Republik Indonesia yang notabene adalah perwakilan dari partai-partai politik, untuk turut serta menentukan proses rekrutmen kepemimpinan di KPK. mekanisme semacam ini menimbulkan kerawanan politik bagi kepemimpinan di tubuh KPK, sehingga dugaan-dugaan adanya konsensi politik tertentu antara KPK dan DPR tidak dapat dihindarkan. Fungsi pencegahan KPK juga harus dikatakan atau dijabarkan secara jelas dan rinci didalam undang-undang. Seiringan dengan berjalannya waktu dan perkembangan teknologi, tindak pidana korupsi akan semakin banyak modusnya, maka dari itu sudah seharusnya KPK sebagai lembaga yang berwenang untuk melakukan tindakan-tindakan pencegahan tindak pidana korupsi terus melakukan pengawasan terhadap lembagalembaga pemerintah terutama pengawasan kepada hal pengadaan barang dan jasa secara elektronik. Hal yang dapat dilakukan dapat berupa pembentukan tim investigasi, pembentukan tim gabungan untuk mengawasi dalam hal pengadaan barang dan jasa secara elektronik, memperketat pengawasan dalam hal pengadaan barang dan jasa secara elektronik, melakukan kerja sama bersama instansi ataupun lembaga yang terkait dengan pengadaan barang dan jasa secara elektronik. Peraturan Presiden tentang strategi pencegahan ataupun peraturan atau dasar hukum lainnya yang berkaitan dengan hal ini juga harus lebih mendetail dimana saja atau apa saja lembaga mana saja yang harus dilakukan monitoring untuk dapat lebih efektif untuk melakukan pencegahan korupsi.

\section{DAFTAR PUSTAKA}

\section{A. Buku}

Apeldoorn, van. Pengantar Ilmu Hukum, (Jakarta: Pradnya Paramita, 2011). 
Arief, Barda Nawawi. Bungi Rampai Kebijakan Hukum Pidana (Perkembangan Penyusunan Konsep KUHP Baru). (Jakarta: Kencana, 2011).

Djaja, Ermansyah. Memberantas Korupsi Bersama KPK. (Jakarta: Sinar Grafika, 2010).

Djamali, R. Abdoel. Pengantar Hukum Indonesia Edisi Revisi. (Jakarta: Rajawali Pers, 2010).

Effendy, Marwan. Korupsi \& Strategi Nasional Pencegahan Serta Pemberantasannya. (Jakarta: Referensi, 2013). Sistem Peradilan Pidana Tinjauan Terhadap Beberapa Perkembangan Hukum Pidana. (Jakarta: Referensi, 2012).

Kusumaatmadja, Mochtar dan Arief Sidharta, Pengantar Ilmu Hukum Suatu Pengenalan Pertama Ruang Lingkup Berlakuknya Ilmu Hukum, Buku I, (Bandung: Penerbit Alumni, 2000).

Mertokusumo, Sudikno. Bunga Rampai Ilmu Hukum. Cetakan ke-1. (Yogyakarta: Liberty, 1984).

Purwosusilo, Aspek Hukum Pengadaan Barang dan Jasa. (Jakarta: Kencana, 2014).

\section{B. Peraturan Perundang-undang}

Indonesia. Undang-Undang Dasar Negara Republik Indonesia Tahun 1945. Cetakan ke-5. (Jakarta: Kepaniteraan dan Sekretariat Jenderal Mahkamah Konstitusi RI, 2015).

.Undang-Undang Nomor 31 Tahun 1999 tentang Pemberantasan

Tindak Pidana Korupsi. (Lembaran Negara Republik Indonesia Tahun 1999 Nomor 140).

.Undang-Undang Nomor 20 Tahun 2001 tentang perubahan atas

Undang-Undang Nomor 31 Tahun 1999. (Tambahan Lembaran

Negara Republik Indonesia Nomor 3874).

.Undang-Undang Nomor 30 Tahun 2002 tentang Komisi

Pemberantasan Tindak Pidana Korupsi. (Lembaran Negara Republik

Indonesia Tahun 2002 Nomor 137). 
. Peraturan Presiden Nomor 54 Tahun 2010 tentang Pengadaan Barang/Jasa Pemerintah.

. Peraturan Komisi Pemberantasan Korupsi Nomor 15 Tahun

2015 tentang Organisasi dan Tata Kerja Komisi Pemberatantasan Korupsi.

\section{Internet}

Abu Samman Lubis, “Aspek Hukum Dalam Pengadaan Barang Dan Jasa Pemerintah", www.bppk.kemenkeu.go.id, 11 Januari 2011

Badan Pusat Statistik, “Statistik Kriminal 2017”, www.bps.go.id, Diakses 30 Agustus 2018

Komisi Pemberantasan Korupsi, “Tentang KPK”, www.kpk.go.id,

Lembaga Kebijakan Pengadaan Barang/Jasa Pemerintah, "Tentang Kami”, www.lpse.lkpp.go.id.

Sudut Hukum, "KPK Merupakan Lembaga Negara Bantu", www.suduthukum.com, 30 Mei 2017 